\title{
IMPROVING STUDENTS' ACHIEVEMENT IN SPEAKING BY USING PICTURE
}

\author{
Marina Sari Rambe \\ Universitas Muslim Nusantara Al Washliyah
}

\begin{abstract}
Learning Language as well as learning English is also the implementation of searching knowledge. The goals in language learning is the students are able to speak English well and use English as their language to communicate with another people in daily life. In language learning, speaking is one of the important things to have, but the students are not able to speak up in English class. Using media is one of the way that can improve the students achievement in speaking class. The researcher will be focus to use picture as media in this research. The researcher formulate there is an improvement of students achievement in speaking by using picture as the problem in this research. The researcher use Classroom Action Research (CAR) Method to analyze the data in this research. The researcher take the first year students of MTS N 2 Medan as the population and 30 students as sample where the researcher get the sample by random. The research take 2 cycle in this research. The instrument to applied to collect the data was speaking test. Besides that, the writer also used interview, observation sheet and diary note to identify what happened in the classroom. After analyzed the data, it was obtained that means increased from the Test-1 in cycle I 71,73\% until test-3 in cycle II 83,40\% and the total score increased $90.0 \%$. So, the use of picture improve students' speaking achievement.
\end{abstract}

\section{Introduction}

\subsection{The Background of Study}

Learning language as well as learning English is also the implementation of searching the knowledge. The goals in English learning is enable to use English in communication in daily life. Speaking is one of the important thing in language learning. There are many ways in teaching English, especially for speaking class, using media to teach speaking class is one of the interest way. Asyik (2000:1) states that, therefore every English teacher who is involve in teaching and learning process, usually faces the same cases such as how to teach English well. In this case the researcher use picture as media to teach in Speaking class. The using of picture hopefully can improve the students achievement in speaking. Picture also the interest one that can motivate the student to try speak up in teaching learning process.

\subsection{The Problem of Study}

The problem of study in this research formulate as.

1. Are there the improvement students achievement in Speaking by using Picture? 
2. What is the advantages of using picture in speaking class?

3. What is the weakness of using picture in speaking class?

\subsection{The Scope of Study}

To scope the study around the focus, the researcher will be use the picture as a media to increase the achievement of the student in speaking. The conversation will be practice based to the picture, and the student will explaine what the picture about. In this case the topic will be discusse by the students, the student will be choose what topic are intepret from the available picture. The picture to be use as a media will be take from magazines, phamplets and text book.

\subsection{The Objective of Study}

In relation to the problem mention above, the objectives of study are

1. to know how far that the student can speak english by using picture.

2. To know what is the advantages of using picture in speaking class.
3. To know the weakness of using picture in speaking class.

\subsection{The Significance of Study}

The findings of this study are expected tobe useful for:

1. English Teacher, in order to motivate their students in learning English.

2. English Students, in order to improve their achivement in speaking

3. For other researchers, to conduct more depth research in teaching of speaking to young learners.

\section{Method}

Somekh (2006:6-7) said that Action research integrates research and action in a series of flexible cycles involving, holistically rather than as separate steps: the collection of data about the topic of investigation, analysis and interpretation of those data, the planning and introduction of action strategies to bring about positive Changes, and evaluation of those changes through further data collection, analysis and interpretation and so forth to other flexible cycles 
until a decision is taken to intervene in this process in order to publish its outcomes to date. Because action research is an integral part of the ongoing activities of the social group whose work is under study, the cyclical process.

Wallace (1998:16-17) describe that action research refer to the classroom investigation initiate by researchers, perhaps teachers, who look critically at their own practice with the purpose understanding and improving their teaching and the quality of the education.

\subsection{Population and Sample}

The population of this reseacrh is the second year students of MTS Negeri 2 Medan. And the sample of the population is one class that consist of 30 students' population. The researcher choose this class because, the writer believed that the student in this class can show their improvement their speaking achievement by using picture as a media.

\subsection{The Instrument of Collecting Data}

The quantitave data will be taken from the test result which carry out in two cycles and every cyle consist of three meetings. The writer only make 3 test, reorientation test, Test-2 in cycle I and Test 3 in cyle II. The qualitative data will be taken from the interview, note book, and the observation sheet.

\subsection{Procedure of Data Collection}

The procedure of data collection of the study will be conduction by administrating for two cycle. In this include four steps, that we call Planning, Action, Observation and Reflection.

There are two cycle will conducted by the writer, for each cycle the writer will be carriying three meetings.

\subsection{Technique of Data Analysis}

This research will produced qualitative and quantitative data. The qualitative data was produce to described the situation in the class when teaching and learning processed. The quantitative data was produce to analyzed the score of the student. The qualitaive data was analyze from interview sheet, observation sheet and diary note and the quantitative data was analyzed from the sccore of the sudents' speaking test. 
The writer applied the following formula to know the score of the students' for each cycle.

$$
\bar{x}=\frac{\sum x}{N} \times 100 \%
$$

Where: $\quad \bar{X}=$ the mean of the students

$$
\sum X=\text { the total }
$$

score

$$
N=\text { the number }
$$

of the sudent

$$
P=\frac{R}{T} \times 100 \%
$$

Where: $\mathrm{P}=$ the percentage of students who get point 75

$$
\mathrm{R}=\text { the number of students }
$$

who get point up 75

$$
\mathrm{T}=\text { the total number of }
$$

students who do the test.

\section{Review Of Literature}

\subsection{SPEAKING}

Speaking is the ability of each person. Usually if some one want to deliver their idea or want to say something the speak to the other people. Speaking also the process of communicating which is convey to deliver some massage to the listener. A speaker must be confident to speak in front of alot of people to deliever what they want to say, and also the speake must be have good pronounciation because if the speaker is not have good pronounciation the listener will be confuse to understand what the speaker say.

\section{Communication}

is

a

collaborative achievement in which the speakers negotiate meaning in order to achieve their goals (Nunan, 1999 :236). It means that in order to interact, the speaker and the listener must be understand one another.

When the teacher teach speaking in the class, the teacher must be try to improve the students achievement every they have english class. Good speaking activity must be engage the students by making them want to take part. It means that the student should be active in the class. The keys which can make the students want to speak in the class are, the teacher must be increase the confidence of the student and also the teacher must be motivate the student to speak in the class. Because according to Daryanto (2010 : 70) the good result from teaching and learning process of the student is based to the teacher, because the teacher determine the students' fate. 
Here are the diagram of the statements:

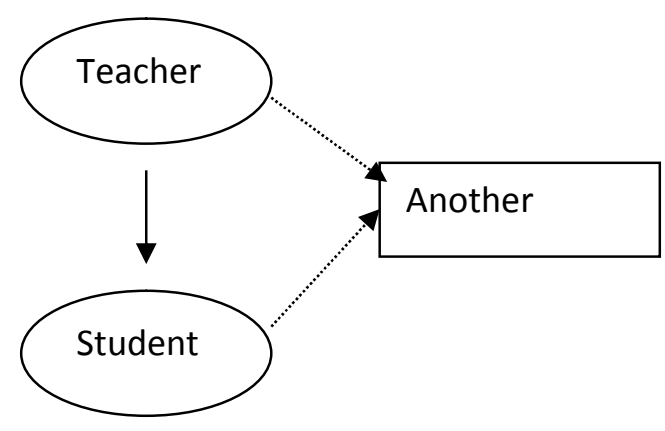

Explanation:

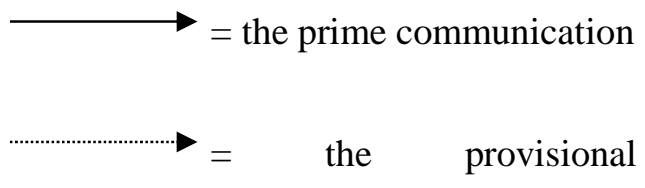

communication

Diagram 2.1

\subsection{The Nature of Speaking}

Language is human and noninstinctive method of communicating idea, feelings, desire by means of a system of sound symbol Hornby (1968:225).

In relation to speaking, Nunans (1999:225) points out some aspect to disscuss:

"The nature of speaking"

1) Characteristic of communicative competetence
2) Discourse versus dialogue

3) Transactional and interactional language

Fom that we can say that the nature of speaking is the activity to verbalize grammatically organized meaningful words as a means of expressing idea, feelings and desire.

Speaking can not separated from listening, beause the activities of speaking will do by two or more person. One, who as the speaker will be deliever the knoeledge to the other, or who one does not know a knowledge and only as a listener.

\subsection{Genre}

Genre has been teorised from a range persepective, including literely studies, popular culture, linguistic, pedagogy and more recently. According to Knapp and watkins (2005) genre or genre thory as it has been developed in literacy education is an organizing concept for cultural practice. It means that genre is place occasion, function, behaviour and interaction structure.

Based Gerrot and Wingell mean (1994:18) genre can be define as a culturally spesific text type which result for using langguage (writen or 
spoken) to (help) accomplish something. It means that genre determine the configuration of field, tenor and mode.

\subsection{Media}

According to Arsyad (1997:3) the defenition of media is intermediary or the delievery massage from the deliever to the receive of the massage. It means that media is the intermediary to say some thing.

Gerlach \& Ely (1971) say that if the media understood the outline is human, material, or events that establish the conditions that make human beings acquire knowledge, skills and attitudes.

Media also have the advantages in teaching and learning process. According to Kemp \& Dayton (1985:3-4)

1) Lessons more interesting

2) Lesson more interesting

3) Long learning time required can be short

4) Quality of learning outcomes can be improve

5) Positive attitude towards students what they learned and the learning process can be enhanced
6) Teacher's role may change towards more positive

\subsection{Picture}

Harmer (1987:23) states that the teachers can use pictures for structural pictures for persentation. In this case, picture can help the teache teach in the class. Teacher can use the picture as the source of the lesson that the teacher teach to the student.

Picture should certainly be subjected to some practical criterion for assesment of their value, but such criterion should apply to all activities wheter their involve picture or not Wright (19998:2)

From the explanation about picture, it can be conclude as follows (Sujana 1991)

1) Pictures illustration is a teaching tool that can attract the students' interest effectively.

2) Pictures illustration is the tool of abstract level that can be interpereted based on past experiences, through words interpretation.

3) Picture illustration help the students to read lesson book, especially in intrepereting and 
recalling the content of the test in it.

4) in booklet, students usually like full or half picture page which are accompanied with clear instruction. It will bw better if more than a half book contains picture illustration.

5) the contentn of pictures illustration must be related to the real life so that the students interest will be effective.

6) the content of the pictures illustration should be will arrangeed as such that will not be contastive with observer's eye; and most important parts of the illustration must be focused on the left above the picture center.

According to Wright (1988:5) there are five criteria of picture which are use by the teacher in the classroom. They are:

1) Easy to prepare

2) Easy to organize

3) Interesting

4) Meaningful and Authentic

5) Sufficient among of the langguage

\subsubsection{Picture as Media}

Picture as media it means that, the picture as the source of the study. In other word we can say that, using media in teaching and learning process can improve the student motivate to study about the lesson.

And also for the teacher, picture make the teacher easier to teach the student. Picture also can increase the students' imagine, because of that the student want to say somehing about what the can see from the picture. It means that the picture can make the student speak to deliever their massage to the other people.

\subsection{Achievement}

According to Brainy Quote the definition of achievement is The act of achieving or performing, an obtaining by exertion, successful performance; accomplishment, as the achievement of his object.

Travers (1970: 447) states that achievement is the result of what an individual has learned from some educational experiences. Additionally, De Cecco \& Crawford (1977) state that achievement is the expectancy of finding satisfaction in mastering challenging and difficult performances.

\subsection{Conceptual Framework}

Speaking is one of the basic in studying language. Speaking also as 
the tool to hve communicatiob to the other people. When speak, the speaker try to give the information or deliever some massage to the listener.

Speaking is abilty, it means that if the students want to speak fluenty, the student must be dilligent to try speak english. Speaking is also the ability waht they want to express for the other people.

\section{Data And Data Analysis}

\subsection{The Data}

This study applied Qualitative and Quantitative data. The quantitative data were taken from the mean of the students' score of assessment in each treatment. The qualitative data were taken from observation sheet, interview sheet,and diary note. This research was conducted in one class with 30 students. It was accomplish in two cycles, consisted of four seps of action research (Plan, action, Observation, and Reflect). The first cycle was conducted in three meetings. The second cycle was conducted in three meetings so there were six meetings altogather. There were two test in first cycle and one test in second cycle.

\subsection{Data Analysis}

\subsubsection{Quantitative Data}

The improvement of the students mean kept growing from the reorientation test until test-3 in cycle II.

In reorientation test, the total score of the students was 1444 and number of the students was 30 students who took the test, so the mean of the students was:

$$
\bar{x}=\frac{2152}{30} \times 100 \%=71.73 \%
$$

In Test-2 in cycle I, the total of the students was 2320 and the number of the students who took the assessment was 30 students, so the mean of the students was:

$$
\bar{x}=\frac{2320}{30} x 100 \%=77,33 \%
$$

In Test- 3 in cycle II, the total of the students was 2502 and the number of the students who took the assessment was 30 students, so the mean of the students was:

$$
\bar{x}=\frac{2502}{30} x 100 \%=83.40 \%
$$

The number of the improving students was calculated as follows:

$$
\begin{aligned}
& \mathrm{P}=\frac{R}{T} \times 100 \% \\
& \mathrm{P} 1=\frac{18}{30} \times 100 \%=60.0 \%
\end{aligned}
$$




$$
\begin{aligned}
& \mathrm{P} 2=\frac{26}{30} \times 100 \%=86.6 \% \\
& \mathrm{P} 3=\frac{27}{30} \times 100 \%=90,0 \%
\end{aligned}
$$

Where:

$\mathrm{P}=$ the percentage of students who get the point 75 up

$\mathrm{R}=$ the number of students who get the points up 75

$\mathrm{T}=$ the total number of the students who do the test

$\mathrm{P} 1=$ the percentage of improvement students in test- 1 in cycle I

$$
\begin{aligned}
\mathrm{P} 2= & \text { the percentage of } \\
& \text { improvement students } \\
& \text { in test- } 2 \text { in cycle I } \\
\mathrm{P} 3= & \text { the percentage of } \\
& \text { improvement students } \\
& \text { in test- } 3 \text { in cycle II }
\end{aligned}
$$

There was $60.0 \%$

students) whose point 75 up in test-1

cycle I . In test- 2 cycle I there was $86.6 \%$ (26 students) whose point 75 up. While in test-3 in cycle II there was $90.0 \%$ (27 students ) whose point up 75. this shows that there was an improvement the mean of the students from test- 1 in cycle I to test3 in cycle II (71.73 to 83.40) .

After analyzing all data, it was concluded that the students' score had improved from the test-1 cycle I to test-3 in cycle II.

It was described as follows:

- Students whose score improve about 5-10 was 11 (GS, HA, JN, MS, NA, SAR, TT, UB, VSR, WS, YN)

- Students whose score improve about 11-20 was 19 (AU, AN, AZ, BA, BI, BN, CI, DA, EA, FH, HM, JF, LR, PR, SD, TMY, USM, VS, WY)

\subsubsection{Qualitative Data}

While doing the First time, there were many students couldn't said anything and confused because they were shy to speak in front of the class. They felt that was difficult to speak in English during teaching and learning process.

\subsubsection{The Data of Cycle I}

There were many activities which were done in this cycle. The teacher use English to explain about recount, narrative and descriptive to the students. For the first time the student fell confused and boring. Because they did not understand what the teacher said. When the teacher motivated and asked them to speak in English, they look liked happy. After that the teacher give them picture for example PETS. One of them asked to speak in front of the class and describe what their know about their pets and also describe to their friends about their pets.

After finished by using the picture. Before the teacher closed the teaching and learning process. The teacher asked them to speak in English during teaching and learning process and also the teacher asked 
them to tell their experience for all of their friends. The teacher asked them like that because it can made the students easy and also built the confidence of the students.

\subsubsection{The Data of Cycle II}

There were also many activities which were done in this cycle. As the opening of learning activity. The teacher asked them to speak about their ability every day. The students gave their good response for the teacher. It was different from the first cycle. In this cycle the students actively and also speak English in the class during teaching and learning process. The teacher gave them the picture about the view and asked them who wants to speak in front of the class and made story from the picture and all of the students raise their hands and speak one by one.

After by using the picture, before the teacher closed the teaching and learning process, the teacher asked them to got a partner and tried to make conversation from the picture that the teacher gave for them. After finished the teacher ask them to practice it in front of the class with their partner. They were very happy and enjoyable to speak and study English by using Picture.

\subsection{Findings}

a. The result of research indicated that there was an improvement of students' speaking achievement which is used by picture. It was proved by the data which showed that the mean of the students' score in test-3 in cycle II $(83,40 \%)$ was higher than the score of the test- 1 in cycle I $(71,73 \%)$ and test- 2 in cycle I $(77,33 \%)$

b. The qualitative data which were taken fro interview, observation sheet and diary note also showed that the students' interest in speaking learning increased, because they could to speak up what their think with the context and deliver their opinion which were provided by picture. They got their learning interest, they found that learning speaking was not difficult, boring and shy to speak.

c. There are so many the advantages of using picture when speaking class, beside the students interest to see and try to speak up, picture also build the students vocabulary, so they improve their vocabulary.

d. The weakness of using picture is not easy to make the new thing to be the media in the class.

\section{CONCLUSION}

\subsection{Conclusion}

After analyzing the data, it was found out the students' score increased from the test- 1 until test- 3 the improvement of the students' speaking achievement by using picture. It was found out that the students score increased from the test- 1 cycle I, Test- 2 in cycle I until test-3 in cycle II. It can be seen from the increasing the mean from 71.73 , 77.33 to 83.40 , the percentage is about $90.0 \%$ increasing students' score. 
During the observation the students talking time was more maximizing than the teacher talking time. The students analyzed and then evaluated what was speak by using picture. Therefore they become confident to speak in class. Maximized of students talking practiced their English. It means the students speaking achievement had improved by using picture.

\subsection{Suggestion}

The result of this study shows that the use of picture could improve students' speaking achievement. The following suggestion offered:

To English teacher, it is better to use picture to make the teaching and learning more interested, it is suggested to made variation the suitable picture for the students and also picture can made the students enjoyable to speak.

To the students, it is suggested to use relevant topic to conduct further research by using picture and also tried to speak English during Teaching and Learning Process.

\section{Refrences}

Arsyad, Azhar Prof. 1996. Media Pembelajaran. Semarang: Raja Grafindo Persada.

Asyik, Abd Gani. 2002. Metode Mengajar Bahasa Inggris. Bandung. Tarsito.

De Cecco, John P., and Crawford, William R. 1974. The Psychology of Learning and Instruction. Educational Psychology. New Jersey: Prentice-Hall, Inc., EnglewoodCliffs.

Daryanto Drs. 2010. Belajar dan Mengajar. Bandung: Yrama Widya
Harmer, J. 2003. How to Teach English. Harlow: Longman, Pearson Education Limitation.

Hornby, A. S. 1975. Guide to Pattern and Usage in english. Harlow: Longman, Person Education Limitation.

Gerlach, V. G. And Ely, D. P. 1971. Teaching and Media. A Systematic Approach. Englewood Cliffs: Prentice-Hall, Inc.

Gerot, L and Wignell, P. 1994. Making Sense on Functional Grammar. Sydney: Gerd stabler.

Kemp, J. E. And Dauton, D. K. 1985. Planning and Producting Intsrtuctional Media (Fifth Edition). New York: Harper \& Row, Publisher.

Nunan, D. 1999. Practical English Language Teaching. New York: Mc. Graw Hill.

Somekh, Bridget. 2006. Action Research: A methodology for Change and Development. McgrawHill Education. Open University Press.

Travers, John P. 1970. Fundamentals of Educational Psychology. Scrantom, Pensylvania: International Textbook Company.

Wallace, M. J. 1998. Action Research for Language Teacher, Cambridge: Cambridge University press.

Wright, Andrew. 1998. Picture for Language Learning. Cambridge: University Press 